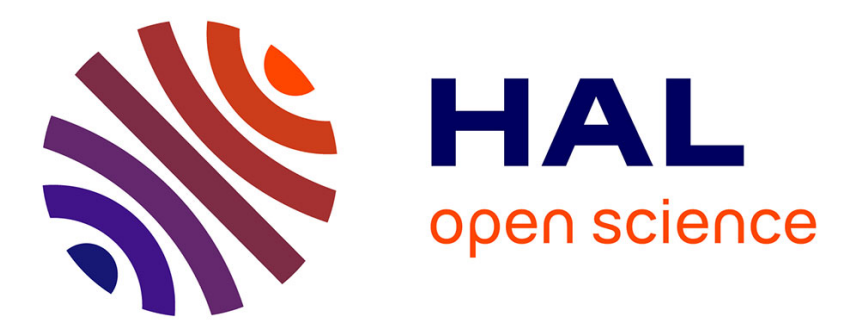

\title{
Partial cloning of CB1 cDNA and CB1 mRNA changes in stress responses in the
}

\author{
F.A. Palermo, B. Ruggeri, G. Mosconi, M. Virgili, A.M. Polzonetti-Magni
}

\section{To cite this version:}

F.A. Palermo, B. Ruggeri, G. Mosconi, M. Virgili, A.M. Polzonetti-Magni. Partial cloning of CB1 cDNA and CB1 mRNA changes in stress responses in the. Molecular and Cellular Endocrinology, 2008, 286 (1-2), 10.1016/j.mce.2008.01.019 . hal-00531989

\section{HAL Id: hal-00531989 \\ https://hal.science/hal-00531989}

Submitted on 4 Nov 2010

HAL is a multi-disciplinary open access archive for the deposit and dissemination of scientific research documents, whether they are published or not. The documents may come from teaching and research institutions in France or abroad, or from public or private research centers.
L'archive ouverte pluridisciplinaire HAL, est destinée au dépôt et à la diffusion de documents scientifiques de niveau recherche, publiés ou non, émanant des établissements d'enseignement et de recherche français ou étrangers, des laboratoires publics ou privés. 


\section{Accepted Manuscript}

Title: Partial cloning of CB1 cDNA and CB1 mRNA changes in stress responses in the Solea solea

Authors: F.A. Palermo, B. Ruggeri, G. Mosconi, M. Virgili, A.M. Polzonetti-Magni

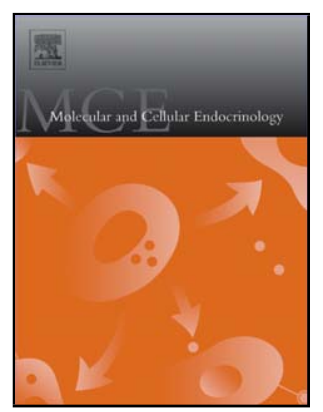

PII:

DOI:

Reference:

To appear in:

Received date:

Revised date:

Accepted date:
S0303-7207(08)00029-4

doi:10.1016/j.mce.2008.01.019

MCE 6807

Molecular and Cellular Endocrinology

22-1-2008

23-1-2008

Please cite this article as: Palermo, F.A., Ruggeri, B., Mosconi, G., Virgili, M., Polzonetti-Magni, A.M., Partial cloning of CB1 cDNA and CB1 mRNA changes in stress responses in the Solea solea, Molecular and Cellular Endocrinology (2007), doi:10.1016/j.mce.2008.01.019

This is a PDF file of an unedited manuscript that has been accepted for publication. As a service to our customers we are providing this early version of the manuscript. The manuscript will undergo copyediting, typesetting, and review of the resulting proof before it is published in its final form. Please note that during the production process errors may be discovered which could affect the content, and all legal disclaimers that apply to the journal pertain. 


\section{Partial cloning of CB1 cDNA and CB1 mRNA changes in stress responses in the Solea solea}

Palermo F.A. ${ }^{1,2}$, Ruggeri B. ${ }^{1}$, Mosconi G. ${ }^{1}$, Virgili M. ${ }^{1}$, Polzonetti-Magni A.M. ${ }^{1,2}$

${ }^{1}$ Dipartimento di Scienze Morfologiche e Biochimiche Comparate, Università degli Studi di Camerino, via Gentile III da Varano, 62032 Camerino (MC), Italy.

${ }^{2}$ Centro Universitario di Ricerca per lo Sviluppo e la Gestione delle Risorse dell'Ambiente Marino e Costiero (UNICRAM), Università degli Studi di Camerino, 63039 San Benedetto del Tronto (AP), Italy.

Running title: $\mathrm{CB} 1 \mathrm{mRNA}$ and stress responses in Solea solea

Keywords: CB1 receptor mRNA, POMC mRNA, stress responses, Solea solea

Address for correspondence:

Prof. Alberta Maria Polzonetti-Magni

Dipartimento di Scienze Morfologiche e Biochimiche Comparate

via Gentile III da Varano, 62032 Camerino (MC) Italy

tel: $++39 / 0737-402740$

fax: $++39 / 0737-402738$

e-mail: alberta.polzonetti@.unicam.it 


\begin{abstract}
Endogenous cannabinoids, through the CB1 receptor, are involved in the control of several functions including stress responses. The aim of this study was to investigate the presence of cannabinoid receptor $\mathrm{CB} 1$ in the sole ovary by partial cloning of brain $\mathrm{CB} 1 \mathrm{cDNA}$; in a stress paradigm of disturbance by handling, which consisted in catching, netting and hand-sorting, changes of CB1 mRNA were related with those of proopiomelanocortin (POMC) mRNA; the trend and timing of stress responses and adaptation were monitored by measuring plasma cortisol levels. We characterized two forms of CB1-like receptor, termed CB1A and CB1B. The two sole CB1 (both $799 \mathrm{bp}$ ) share $76 \%$ identity in their cDNAs, and the deduced amino acid sequences are $80 \%$ identical. The handling stress induced a sustained increase in plasma cortisol levels $1 \mathrm{~h}$ after the handling began and decreased to low levels $12 \mathrm{~h}$ after initiation of handling, showing the same trend of ovarian POMC mRNA expression. In addition, while CB1A mRNA did not show any significant changes during handling stress, significantly lower levels of CB1B mRNA were found in stressed fish $1 \mathrm{~h}$ after the beginning of handling, with CB1 expression increased $24 \mathrm{~h}$ after stress induction, both in the ovary and brain. It can be concluded that endocannabinoid system is involved in the modulation of adaptive responses to environmental conditions.
\end{abstract}




\section{Introduction}

The cannabinoid receptor CB1 mediates the psychoactive effect of marijuana, derived from the Cannabis plant, one of the most commonly used recreational drugs. In mammals, there is abundant evidence for the importance of cannabinoid signalling; activation of CB1 exerts diverse functions, chiefly by its ability to modulate neurotransmission, and thus much attention has been devoted to understanding its role in health and disease and to evaluating its therapeutic potential.

The discovery of CB1 cannabinoid receptors in the mammalian central nervous system (CNS) (Devane et al., 1988; Matsuda et al., 1990) followed by the characterization of two CB1 genes (CB1A and CB1B) in the brain of a bony fish (Fugu rubripes) by Yamaguchi et al (1996), aroused interest in the phylogeny of the cannabinergic signalling system. Phylogenetic trees of CB1, the Gprotein-coupled receptor, have been proposed (Soderstrom et al., 2000; Elphick and Egertovà, 2001; Cottone et al., 2003), suggesting that CB1 cannabinoid receptors are present in the nervous system of the majority of vertebrates (Cesa et al., 2001; Salio et al., 2002; Cottone et al., 2005; Meccariello et al., 2006). Endogenous cannabinoids, through the CB1 receptor, are involved in the control of several functions, particularly, in the regulation of gonadotropin-releasing-hormone (GnRH) secretion at the central level (Gammon et al., 2005; Cottone et al., 2007), and in inhibiting pituitary hormone release (Ho et al., 2000; Murphy et al., 1999). At the peripheral level, the presence and involvement of $\mathrm{CB} 1$ receptor in the modulation of gonadal development and differentiation has been studied in the proterandrous teleost species, Sparus aurata, (Ruggeri et al., 2006), and other studies conducted by Meccariello et al. (2006) and Cottone et al. (2005b),

The cannabinergic system is also involved in the response to environmental modifications and modulation of adaptation mechanisms. Research in rodents has added evidence that endocannabinoids are involved in modulating emotional and affective responses to stressful stimuli (Patel et al., 2004, 2005; Viveros et al., 2005). Recently, Coddington et al (2006) demonstrated that endocannabinoids mediate the effects of acute stress and corticosterone on sex behaviour of Taricha 
granulosa, as an amphibian model. Numerous studies in a variety of vertebrates document that concentrations of adrenal steroid hormones, namely cortisol or corticosterone, increase shortly after exposure to stressful conditions. In teleost species, the activation of the hypothalamus-pituitaryinterrenal (HPI) axis elicits plasma cortisol increases in response to different stress paradigms (Mosconi et al., 2006). Responses to stress, chiefly adaptation are also mediated by neuroendocrine loops that include opioid peptides (Mosconi et al., 1998) and the cannabinoid signalling system. In fact, on the basis of the neuroanatomical distribution of $\mathrm{CB} 1$ at the central and peripheral level (Cottone et al., 2007), and relationship with a number of other signalling molecules, the fish CB1 cannabinoid receptors can be considered modulators in endocrine and behavioural output, in particular, in stress responses.

Solea solea is a teleost of great commercial interest, and is considered a new species for sustainable aquaculture, in which fish health and wellness are obviously of prime importance, and measures to improve the ways the fish are bred, raised, and processed play a crucial role.

In the experiments described below, we investigated the presence of cannabinoid receptor CB1 in the sole ovary by partial cloning of CB1 cDNA. In a stress paradigm consisting in the handling stress, changes of CB1 mRNA were compared to those of proopiomelanocortin (POMC) mRNA, and the trend and timing of stress response and adaptation were monitored by measuring plasma cortisol levels.

\section{Material and methods}

\subsection{Animals}

A stock of female sole (Solea solea) between 0.2 and $0.3 \mathrm{~kg}$ body weight was obtained in February 2006 from an Italian fish farm, Orbetello Pesca Lagunare s.r.l. (Comune di Orbetello GR; $42^{\circ} 26^{\prime} 13^{\prime \prime} \mathrm{N}, 11^{\circ} 12^{\prime} 30^{\prime \prime} \mathrm{E}$, Localita` Santa Liberata), and maintained in indoor tanks with $1 \mathrm{~m}$ water depth. All tanks were connected to a recirculating plant equipped with U.V. and biological filters, and illuminated with artificial light provided by two neon tubes of 40 watts each. Water was 
changed four times a day and water quality parameters were monitored weekly, showing the following ranges: dissolved oxygen $6.7-8.0 \mathrm{ppm}$, salinity 34-36 ppt, and $\mathrm{pH} 7-8$. The water temperature was kept at $11^{\circ} \mathrm{C}$ and a constant 10-h light/14-h dark cycle was maintained. Fish were hand-fed ad libitum twice a day with a semi-moist pellet produced every 20 days and stored at -20 ${ }^{\circ} \mathrm{C}$. The fish were not fed $24 \mathrm{~h}$ prior to or during the experiment.

Two weeks before the beginning of the experiment, sixty fish from the stock population were divided into twelve $0.3 \mathrm{~m}^{3}$ tanks supplied with seawater (temperature $11^{\circ} \mathrm{C}$, dissolved oxygen 6.7 8.0 ppm, salinity 34-36 ppt, and pH 7-8). Two tanks (five fish per tank) were assigned to each time point during the trials: $1 \mathrm{~h}, 12 \mathrm{~h}$, and $24 \mathrm{~h}$. Fish were subjected to a standardized stress protocol of disturbance by handling, that is, catching, netting and hand-sorting for $1 \mathrm{~min}$ and were left undisturbed until they were sampled. Six tanks (five fish per tank $=$ a total of 30 fish) were maintained exactly as mentioned above as unstressed controls and sampled at 1, 12, and $24 \mathrm{~h}$.

Fish were anaesthetized with MS $222\left(100 \mathrm{mg} \mathrm{L}^{-1}\right)$ by adding anaesthetic directly to experimental tanks. Following the rapid induction of anaesthesia, fish were immediately netted and blood was collected from the caudal vein into heparinized syringes and centrifuged (1500g for 15 min at $4{ }^{\circ} \mathrm{C}$ ); the plasma was stored at $-20^{\circ} \mathrm{C}$ until being assayed. Brain and gonadal tissues were harvested, immediately frozen in liquid nitrogen and stored at $-80{ }^{\circ} \mathrm{C}$ for molecular biology experiments. Animal manipulation was performed according to the recommendations of the University Ethical Committee and under the supervision of the authorized investigators.

\subsection{Total RNA extraction}

Total RNA was extracted from $100 \mathrm{mg}$ of brain and ovary using TRIzol reagent (Invitrogen, Carlsbad, CA) according to the manufacturer's instructions. DNase digestion $\left(45 \mathrm{~min}, 37{ }^{\circ} \mathrm{C}, 2 \mathrm{U}\right.$; Ambion, Austin, TX) was performed to eliminate genomic DNA contamination. To confirm the absence of genomic DNA, the same amount of total RNA as that used for the RT-PCR was added to the RT reaction mixture without reverse transcriptase and was subsequently amplified. 
Quantity and purity of the RNA was assessed spectrophotometrically at 260 and $280 \mathrm{~nm}$, and integrity was confirmed by electrophoresis through $1 \%$ agarose gels stained with ethidium bromide.

\subsection{Reverse transcription-polymerase chain reaction and sequence analysis}

An amount of $2 \mu \mathrm{g}$ of brain total RNA was reverse transcribed with $0.5 \mu \mathrm{g}$ of oligo(dT) primers and $200 \mathrm{U}$ of RevertAid H minus M-MuLV Reverse Transcriptase (Fermentas, Lithuania) in a final volume of $20 \mu \mathrm{l}$. A polymerase chain reaction was performed with degenerate primers, selected by aligning CB1 nucleotide sequences present in the GenBank and choosing highly conserved sequences. The forward primer, corresponding to the N-terminus coding sequence was 5'-ATG GA(T/C) ATG GA(A/G) TG(T/C) TT(T/C) ATG-3' and the reverse primer, corresponding to the seventh transmembrane domain coding sequence was 5'-(A/G)CA (G/A)AA (G/C/T)GC AAA (G/C/A)A(T/C) (C/A)GT CT-3' (Invitrogen Life Technologies, Milan, Italy); those primers delimited a region of $799 \mathrm{bp}$. Three microliters of cDNA was amplified using PCR master mix 2x (Promega) in a final volume of $25 \mu \mathrm{l}$. Cycling parameters were as follows: $94{ }^{\circ} \mathrm{C}$ for $5 \mathrm{~min}$, followed by 35 cycles of $94{ }^{\circ} \mathrm{C}$ for $40 \mathrm{~s}, 54{ }^{\circ} \mathrm{C}$ for $40 \mathrm{~s}$, and $72{ }^{\circ} \mathrm{C}$ for $1 \mathrm{~min}$, with a final extension step of $72{ }^{\circ} \mathrm{C}$ for $10 \mathrm{~min}$.

The final PCR product was electrophoresed in 1.5\% agarose gels, and fragments were isolated, purified using MiniElute Gel Extraction Kit (Qiagen) and ligated into a pGEM-T Easy Vector (Promega Corporation, Madison, WI). Then, Escherichia coli JM109 competent cells (Promega Corporation, Madison, WI) were transformed with the ligation reaction and the colonies were grown on a plate. After selection, clones were screened for appropriate size inserts using restriction endonucleases (Nco I - Spe I; Promega). Plasmid DNA was extracted using QIAprep Spin Miniprep kit (Qiagen) and sequenced. To establish the degree of identity of CB1 among the different species, both the nucleotide and the deduced amino acid sequences of $S$. solea $\mathrm{CB} 1$ were aligned with other CB1 sequences present in GenBank using CLUSTAL W multiple alignment computer programs (Higgins et al., 1996). 


\subsection{Expression patterns of $C B 1$ and POMC $m R N A s$}

RT-PCR was conducted to determine the relative expression of CB1 and POMC mRNA in sole. Total RNA was isolated from ovary and an amount of $10 \mu \mathrm{g}$ was reverse transcribed utilizing $0.3 \mu \mathrm{g}$ random hexamers and $200 \mathrm{U}$ of RevertAid H Minus M-MuLV reverse transcriptase, according to the manufacturer's instructions (Fermentas, Lithuania). The reaction was incubated for 60 min at 42 ${ }^{\circ} \mathrm{C}$. CB1-specific primers for RT-PCR were designated on the basis of the two independent sequences that were found after sequencing previously cloned CB1 mRNA fragment (799 bp). The sequences were named $\mathrm{CB} 1 \mathrm{~A}$ and $\mathrm{CB} 1 \mathrm{~B}$ due to their homology with $F$. rubripes $\mathrm{CB} 1 \mathrm{~A}$ and CB1B. For the PCR, the primers used were 5'-GAG GCT CTT CTG GGA GGT TC -3' (CB1A forward), 5'-TCT CTG ACT CTG GGC ACC TT -3' (CB1A reverse) and 5'-GGC CAC CAG GAT CAG AAC TA-3' (CB1B forward), 5'-CTG CAC TCT CAT ACG CTT CG -3' (CB1B reverse). To verify the expression of POMC mRNA in the ovary, primers (sense: 5'-AGA GAG GGC AGT GTG GAG AA-3'; antisense 5'-GTC AGC TCG TCG TAG CGT TT-3') were chosen according to Palermo et al. (2007).

Relative gene expression was estimated using 18S RNA as a control as it remains constant in many physiological conditions. Initial pilot experiments were performed to determine the linear range of PCR and the ratio of competimers to primers for the $18 \mathrm{~S}$ rRNA (Ambion, USA). The reactions were carried out in a final volume of $25 \mu$ l containing: $12.5 \mu \mathrm{l}$ PCR master mix $2 \mathrm{x}$ (Promega), $12.5 \mu \mathrm{M}$ of each primer and $18 \mathrm{~S}$ primers:competimers. To quantify the expression of CB1A and CB1B receptors, a PCR was carried out for 35 cycles as follows: one cycle of denaturation at $94{ }^{\circ} \mathrm{C}$ for $5 \mathrm{~min}$, denaturation at $94{ }^{\circ} \mathrm{C}$ for $40 \mathrm{~s}$, annealing at $58{ }^{\circ} \mathrm{C}$ for $20 \mathrm{~s}$, and an extension at $72{ }^{\circ} \mathrm{C}$ for $40 \mathrm{~s}$, followed by a final extension step of $72{ }^{\circ} \mathrm{C}$ for $7 \mathrm{~min}$. To determine POMC mRNA expression, PCR conditions were set as follows: $94{ }^{\circ} \mathrm{C}$ for $5 \mathrm{~min}$, followed by 35 cycles of $94{ }^{\circ} \mathrm{C}$ for $30 \mathrm{~s}, 60{ }^{\circ} \mathrm{C}$ for $25 \mathrm{~s}$, and $72{ }^{\circ} \mathrm{C}$ for $30 \mathrm{~s}$, with a final extension step of $72{ }^{\circ} \mathrm{C}$ for $7 \mathrm{~min}$. PCR reactions generated fragments of $585 \mathrm{bp}$ (CB1A), $630 \mathrm{bp}(\mathrm{CB} 1 \mathrm{~B}), 500 \mathrm{bp}$ (POMC) and 324 bp (18S), respectively. 
Gel images were subsequently captured using a digital camera EDAS 290 (Kodak), and the reaction products analyzed using 1D Image Analysis software (Kodak). Normalization was carried out by dividing the average value of CB1A, CB1B or POMC mRNAs by the average value of $18 \mathrm{~S}$ rRNA amplified from the same reversed transcribed templates.

\subsection{Cortisol assay}

Plasma cortisol levels were analyzed by an EIA method (Cayman, USA), using a specific anticortisol antibody. The assay sensitivity was $12 \mathrm{pg} / \mathrm{ml}$, and the inter- and intra-assay coefficients of variation were 6.5 and $4.2 \%$, respectively. Plasma samples were previously extracted with methylene chloride (Cold Spike Extraction) as described by the supplier. To validate cortisol assay for seabream, parallelism between the standard curve and serial dilutions of plasma samples was established (data not shown).

\subsection{Statistical analysis}

All data were analyzed using Sigma Stat 3.1 (Systat software, Inc). Data distributions were first examined for their fit to a normal distribution and homogeneity of variance using KolmogorovSmirnov and Levene median tests. One-way Analysis of Variance (ANOVA) was used to compare results between groups, followed by Tukey post hoc test. Differences between means were considered significant when $\mathrm{P}<0.05$. Results are expressed as means $+\mathrm{SE}$ of data.

\section{Results}

\subsection{Solea solea CB1 sequence analysis}

A polymerase chain reaction was performed with degenerate primers on S. solea brain amplifying a $799 \mathrm{bp}$ fragment. The sequence analysis of the amplified fragment showed the presence of two independent sequences that were named $\mathrm{CB} 1 \mathrm{~A}$ and $\mathrm{CB} 1 \mathrm{~B}$ because of their homology with F. rubripes $\mathrm{CB} 1 \mathrm{~A}$ and $\mathrm{CB} 1 \mathrm{~B}$. The nucleotide sequences of the $\mathrm{CB} 1 \mathrm{~A}$ and the $\mathrm{CB} 1 \mathrm{~B}$ were $76 \%$ identical (Fig. 1), whereas the identity between the deduced amino acid sequences was 
$80 \%$ (Table 1). The deduced amino acid sequences of sole CB1A and CB1B were aligned with other bony fish CB1 sequences present in GenBank (F. rubripes CB1A and CB1B, C. auratus, P. pulcher, Danio rerio and Sparus aurata) using the Clustal W program (Fig.2).

\section{2. $C B 1 A$ and $C B 1 B m R N A$ changes in the ovary}

The mRNA levels of CB1A and CB1B in the ovary following handling stress were assessed through a relative-quantitative $\mathrm{RT} / \mathrm{PCR}$, utilizing ribosomal RNA $18 \mathrm{~S}$ as internal standard. The $\mathrm{CB} 1 \mathrm{~A}$ and $\mathrm{CB} 1 \mathrm{~B}$ transcript levels did not change significantly $(P>0.05)$ in the control groups at different times (Fig. 3). CB1A mRNA levels found in the ovary of stressed fish after $1 \mathrm{~h}, 12 \mathrm{~h}$ or $24 \mathrm{~h}$ were not significantly $(P>0.05)$ different than those found in control group (Fig. 3a). However, compared to the control, significantly $(P<0.05)$ lower levels of CB1B mRNA were found in the ovary of stressed fish after 1 and $12 \mathrm{~h}$; on the contrary, mRNA expression titers of CB1B mRNA did not exhibit any significant changes with respect to the controls $24 \mathrm{~h}$ after handling stress (Fig. 3b). Similar results were found in the brain (data not shown).

\subsection{POMC mRNA changes in the ovary}

Fig. 4 shows that POMC mRNA levels found in the ovary of stressed fish after $1 \mathrm{~h}$ were significantly $(P<0.05)$ higher than that found in the control group. POMC expression decreased thereafter and was not significantly different at 12 and $24 \mathrm{~h}$, respectively $(P>0.05)$ compared to the control group value.

\subsection{Plasma cortisol levels}

Cortisol values showed the typical acute responses, reaching a peak $1 \mathrm{~h}$ after the handling was started (Fig. 5). In fact, the plasma cortisol levels found $1 \mathrm{~h}$ after stress were significantly $(P<0.05)$ higher than those in control group. Values 12 and $24 \mathrm{~h}$ after handling were similar to those of control group. 


\section{Discussion}

These data support the hypothesis that the stress response and cortisol increase require the activation of $\mathrm{CB} 1$ receptors. In addition, for the first time, partial cloning of $\mathrm{CB} 1$ receptor has been performed in the flatfish, Solea solea. Thus, the present findings might indicate a potentially conserved mechanism in fish through which the classic stress steroid, cortisol, exerts its function. It is known that the pattern and mechanisms of stress are conserved around the vertebrates. In fish, stress typically stimulates the secretion of corticosteroids and favors rapid changes in response to acute stress (Mosconi et al., 2006). Furthermore, comparison of the fish HPI axis with the mammalian hypothalamus-pituitary-adrenal (HPA) axis reveals conservation of hormone function and regulation (Norris, 1997). Studies in rodents suggest that the rapid inhibitory effects of corticosterone on hormones in the HPA axis involve the activation of CB1 signaling. Our findings extend the role of $\mathrm{CB} 1$ in the modulation of rapid responses, mediated by cortisol, to handling stress.

The present study reports the partial cloning and expression of mRNA coding CB1-like receptors in mature female sole $(S$. solea). We characterized two forms of CB1-like receptor, termed $\mathrm{CB} 1 \mathrm{~A}$ and $\mathrm{CB} 1 \mathrm{~B}$. The two sole $\mathrm{CB} 1 \mathrm{cDNAs}$ exhibits a 76\% sequence identity to each other. The sole cannabinoid-like receptors $\mathrm{CB} 1 \mathrm{~A}$ and $\mathrm{CB} 1 \mathrm{~B}$ are $80 \%$ identical by amino acid comparison. The deduced amino acid sequences of both CB1A and CB1B were aligned with the other bony fish CB1 sequences showing a high degree of identity between teleost fish. Moreover, sole CB1 A shows high homology to the $F$. rubripes CB1A (94\%), while sole CB1B is $89 \%$ homologous to $F$. rubripes $\mathrm{CB} 1 \mathrm{~B}$. Within the transmembrane domains, these values increase to $95 \%(\mathrm{CB} 1 \mathrm{~A})$ and to $90 \%(\mathrm{CB} 1 \mathrm{~B})$.

Our results regarding the possible existence of two CB1 genes in the genome of a teleost $(S$. solea) are in agreement with those found in F. rubripes concerning the presence of two orthologoues of CB1 (Yamaguchi et al., 1996). The existence of two CB1 genes in sole is another indicator that whole-genome duplication occurs before the divergence of Actinopterigii and 
Sarcopterigii, and one more duplication event in Actinopterigii before the teleost radiation (Taylor and Raes, 2004). Rodriguez-Martin et al. (2007) have demonstrated the presence of two zebrafish CB2-like cannabinoid receptor mRNAs, suggesting the presence of two orthologoues of CB2-like cannabinoid receptor related to a different mechanism, such as a tandem repetition duplication event. The two zebrafish CB2 genes encode proteins that share 95\% sequence identity; similar levels of sequence homology are different from those found in our study on sole CB1.

Teleost fish are, as other vertebrates, quite sensitive to different kinds of stressors; in particular, rearing conditions interfere with neuroendocrine homeostasis and negatively affect reproductive performance. In fact, recently published data agree with the presence of a highly developed cannabinergic system in CNS areas controlling reproduction, in both teleost fish (Cottone et al., 2005a,b) and amphibia (Cesa et al., 2001; Cottone et al., 2003). In addition, endogenous cannabinoids, through the $\mathrm{CB} 1$ receptor, are involved in the regulation of $\mathrm{GnRH}$ secretion at the central level (Gammon et al., 2005) by inducing an inhibitory effect on release of pituitary hormones (Ho et al, 2000; Murphy et al, 1998). Other than on the reproductive axis, the endogenous cannabinoid seems to be involved in the control of the interrenal axis through the changes, here reported, of cannabinoid receptor $\mathrm{CB} 1 \mathrm{~B}$. In the current experiment, handling stress induced a sustained increase in plasma cortisol levels $1 \mathrm{~h}$ after the handling and decreased to low levels after $12 \mathrm{~h}$. Corticosteroids play an important role in the regulation of the behavioural and metabolic responses to stress. Since cortisol secretion is controlled by adrenocorticotropic hormone (ACTH) secreted from the pituitary, an elevation in ACTH level could be related with the opioid system. The trend of POMC mRNA found here behaves differently than that found in a long-term stress paradigm (Palermo et al., 2007), confirming that POMC stress responses, as in other teleost species (Mosconi et al., 2006), mainly depend on the type of stress and its duration. The correlation between cortisol pattern and POMC mRNA changes was in agreement with previous finding on stress in teleost species. In addition, while CB1A mRNA did not show any significant changes during handling stress, significantly lower levels of CB1B mRNA were found in stressed fish after 
$1 \mathrm{~h}$, with increased CB1 expression $24 \mathrm{~h}$ after stress induction, both in the ovary and brain. These data are consistent with the findings by Patel et al. (2004) showing that hypothalamic 2arachidonilglycerol (2-AG) content is reduced and cortisol elevated following an acute stress induction, suggesting that during non-stressful conditions, elevated 2-AG content, leading to an increment of CB1 receptor expression, is closely related to a reduction of HPA axis activity. Our results demonstrated an interesting relationship between environmental stress and endocannabinoid signalling in the regulation of HPI axis activation. The hypothesis is that endogenous CB1B receptor expression is elevated during non-stressed conditions and is reduced during stress, confirming the role of the CB1 receptor as an inhibitor of synaptic activity, and suggesting a role of the endocannabinoid system in stress responses in terms of adaptation to environmental conditions.

\section{Acknowledgments}

This research was funded by grants from the Italian Ministry of the University (MIUR).

\section{References}

Cesa, R., Mackie, K., Beltramo, M., Franzoni, M.F., 2001. Cannabinoid receptor CB1-like and glutamic acid decarboxylase-like immunoreactivities in the brain of Xenopus laevis. Cell Tissue Res. 306, 391-8.

Coddington, E., Lewis, C., Roset, J.D., Moore, F.L., 2003. Neuroendocrinology of contextdependent stress responses: vasotocin alters the effect of corticosterone on amphibian behaviors. Horm. Behav. 43, 222-8.

Cottone, E., Salio, C., Conrath, M., Franzoni M.F., 2003. Xenopus laevis CB1 cannabinoid receptor: molecular cloning and mRNA distribution in the central nervous system. J. Comp. Neurol. 464, 487-496.

Cottone, E., Campantico, E., Guastalla, A., Aramu, S., Polzonetti Magni, A.M., Franzoni, M.F., 2005a. Are the cannabinoids involved in bony fish reproduction? Ann. N. Y. Acad. Sci. 1040, 273276.

Cottone, E., Forno, S., Campantico, E., Guastalla, A., Viltono, L., Mackie, K., Franzoni, M.F., 2005b. Expression and distribution of CB1 cannabinoid receptors in the central nervous system of the African cichlid fish Pelvichromis pulcher. J. Comp. Neurol. 485, 293-303. 
Cottone, E., Donna D., Guastalla A., Campantico E., Polzonetti A., Franzoni M.F., 2007. The cannabinoid signaling system: Comparative biology of an old neuromodulatory system. In: Canonaco, M., Facciolo, R.M., (Eds), Evolutionary Molecular Strategies and Plasticity, Trivandrum: Research SignPost (INDIA), pp. 73-94.

Devane, W.A., Dysarz, F.A.I., Johson, M.R., Melvin, L.S., Howlett, A.C., 1988. Determination and characterization of a cannabinoid receptor in rat brain. Mol. Pharmacol. 34, 605-613.

Elphick, M.R., Egertovà, M., 2001. The neurobiology and evolution of cannabinoid signalling. Philos Trans R Soc Lond B Biol Sci.1407, 381-408.

Gammon, C.M., Freeman, G.M., Xie, W., Peterson, S.L., Wetsel W.C., 2005. Regulation of gonadotropin-releasing hormone secretion by cannabinoids. Endocrinology. 146, 4491-4499.

Higgins, D.G., Thompson, J.D., Gibson, T.J., 1996. Using CLUSTAL for multiple sequence alignments. Methods Enzymol. 266, 383-402.

Ho, B.Y., Stadnicka, A., Prather, P.L., Buckley, A.R., Current, L.L., Bosnjak, Z.J., Kwok, W.M., 2000. Cannabinoid CB1 receptor-mediated inhibition of prolactin release and signaling mechanisms in GH4C1 cells. Endocrinology. 14, 1675-85.

Matsuda, L.A., Lolait, S.J., Brownstein, M.J., Young, A.C., Bonner, T.I., 1990. Structure of a cannabinoid receptor and functional expression of the cloned cDNA. Nature. 346, 561-564.

Meccariello, R., Chianese, R., Cacciola, G., Cobellis, G., Pierantoni, R., Fasano, S., 2006. Type-1 Cannabinoid receptor expression in the frog, Rana esculenta, tissues: a possible involvement in the regulation of testicular activity. Mol. Reprod. Dev. 73, 551-558.

Mosconi, G., Gallinelli, A., Polzonetti-Magni, A.M., Facchinetti, F,. 1998. Acetyl salmon endorphin-like and interrenal stress response in male gilthead seabream, Sparus aurata. Neuroendocrinology. 68, 129-134.

Mosconi, G., Cardinaletti, G., Carotti, M., Palermo, F., Soverchia, L., Polzonetti-Magni, A.M., 2006. Neuroendocrine mechanisms regulating stress response in cultured teleost species. In Reinecke, M., Zaccone, G., Kapoor, B.G., (Eds.), Fish Endocrinology, Science Publishers, Enfield, NH, USA. Vol. 2, pp 693-720.

Murphy, L.L., Munoz, R.M., Adrian, B.A., Villanua, M.A., 1998. Function of cannabinoid receptors in the neuroendocrine regulation of hormone secretion. Neurobiol. Dis. 5, 432-446.

Norris, D.O., 1997. Vertebrate Endocrinology, 3rd ed. Academic Press, San Diego.

Palermo, F., Nabissi, M., Cardinaletti, G., Tibaldi, E., Mosconi, G., Polzonetti-Magni A.M., 2007. Cloning of sole proopiomelanocortin (POMC) cDNA and the effects of stocking density on POMC mRNA and growth rate in sole, Solea solea. Gen. Comp. Endocrinol. 1, 227-233.

Patel, S., Roelke, C.T., Rademacher, D.J., Cullinan, W.E., Hillard, C.J., 2004. Endocannabinoid signaling negatively modulates stress-induced activation of the hypothalamic-pituitary-adrenal axis. Endocrinology 145, 5431-8. 
Patel, S., Cravatt, B.F., Hillard, C.J., 2005. Synergistic interactions between cannabinoids and environmental stress in the activation of the central amygdala. Neuropsychopharmacology 30, 497507.

Rodriguez-Martin I., Herrero-Turrion, M.J., Marron Fdez de Velasco, E., Gonzalez-Sarmiento, R., Rodriguez, R.E., 2007. Characterization of two duplicate zebrafish Cb2-like cannabinoid receptors. Gene. 389, 36-44.

Ruggeri, B., Soverchia, L., Mosconi, G., Franzoni, M.F., Cottone, E., Polzonetti-Magni, A.M., 2006. Changes of gonadal CB1 cannabinoid receptor mRNA in the gilthead seabream, Sparus aurata, during sex reversal. Gen. Comp. Endocrinol. 150(2), 263-9.

Salio, C., Cottone, E., Conrath, M., Franzoni, M.F., 2002. CB1 cannabinoid receptors in amphibian spinal cord: Relationships with some nociception markers. J. Chem. Neuroanat. 24, 153-162.

Soderstrom, K., Leid, M., Moore, F.L., Murray, T.F., 2000. Behaviroal, pharmacological, and molecular characterization of an amphibian cannabinoid receptor. J. Neurochem. 75, 413-23.

Taylor, J.S., Raes, J., 2004. Duplication and divergence: the evolution of new genes and old ideas. Annu. Rev. Genet. 38, 615-643.

Viveros, M.P., Marco, E.M., File, S.E., 2005. Endocannabinoid system and stress and anxiety responses. Pharmacol. Biochem. Behav. 81, 331-42.

Yamaguchi, F., Macrae, A.D., Brenner, S., 1996. Molecular cloning of two cannabinoid type 1-like receptor genes from the puffer fish Fugu rubripes. Genomics. 35, 603-605.

Table 1. Amino acid sequence identity between $\mathrm{CB} 1$ sequences from various species.

\begin{tabular}{lcc}
\hline Species & $\%$ Amino acid sequence identity \\
\hline & Solea solea CB1A & Solea solea CB1B \\
\hline 1. Solea solea CB1A & 100 & 80 \\
2. Solea solea CB1B & 80 & 100 \\
3. Fugu rubripes CB1A & 94 & 81 \\
4. Fugu rubripes CB1B & 77 & 89 \\
5. Danio rerio & 92 & 80 \\
6. Carassius auratus & 89 & 77 \\
7. Pelvicachromis pulcher & 95 & 81 \\
8. Sparus aurata & 95 & 80 \\
\hline
\end{tabular}




\section{FIGURE LEGENDS}

Fig. 1. Alignment of nucleotide sequences from two sole CB1 cDNAs. Asterisks indicate identical nucleotides between $\mathrm{CB} 1 \mathrm{~A}$ and $\mathrm{CB} 1 \mathrm{~B}$. Numbers at the end of each line refer to the nucleotide position.

Fig. 2. Alignment of $\mathrm{CB} 1$ amino acid sequences from different species. Gene bank accession numbers for the different sequences shown in the alignment are: Solea solea CB1A (EU327780); Solea solea CB1B (EU327781); Fugu rubripes CB1A (Q98894); Fugu rubripes CB1B (Q98895); Danio rerio (NP997985); Carassius auratus (AAT76978); Pelvicachromis pulcher (AAS93801) and Sparus aurata (EF051620). Shaded boxes with the Roman numerals indicate the positions of transmembrane domains. Gaps introduced for optimal alignment are indicated by dashes. Identical or conserved residues in all sequences, (:) conserved substitutions and (.) semi-conserved substitutions.

Fig. 3. Effect of handling-induced stress on CB1A (a) and CB1B (b) expression levels in sole $(S$. sole) ovary. Total RNA from sole ovary, at different sampling time, was reverse-transcribed and amplified using sole $\mathrm{CB} 1 \mathrm{~A}$ or $\mathrm{CB} 1 \mathrm{~B}$ specific primers. Changes in signal intensity were determined by densitometry. Results are expressed as arbitrary units (a.u.) of CB1A or CB1B mRNA levels standardized against the levels of $18 \mathrm{~S}$ rRNA amplified from the same reversed transcribed template. Data shown are expressed as mean + S.E.M. $(n=5)$. Difference from control: $* P<0.05$.

Fig. 4. Effect of stress by handling on POMC expression levels in sole (S. sole) ovary. Total RNA from sole ovary, at different sampling times, was reverse-transcribed and amplified using sole POMC specific primers. Changes in signal intensity were determined by densitometry. Results are expressed as arbitrary units (a.u.) of POMC mRNA levels standardized against the levels of $18 \mathrm{~S}$ 
rRNA amplified from the same reversed transcribed template. Data shown are expressed as mean + S.E.M. $(n=5)$. Difference from control: $* P<0.05$.

Fig. 5. Effects of stress by handling on cortisol levels in mature female sole (S. solea). Fish were sampled at $0,1,12$ and $24 \mathrm{~h}$ after the stressor was initiated. The results are given as the mean + S.E.M. ( $n=5$, except at $0 \mathrm{~h}$ when $n=7)$. Columns with asterisk are significantly different from control group $(* P<0.05)$. 
Fig. 1.

CB1A

CB1B

CB1A

CB1B

CB1A

CB1B

CB1A

CB1B

CB1A

CB1B

CB1A

CB1B

CB1A

CB1B

CB1A

CB1B

CB1A

CB1B

CB1A

CB1B

CB1A

CB1B

CB1A

CB1B

CB1A

$\mathrm{CB} 1 \mathrm{~B}$

CB1A

CB1B

ATCCTGACTCCCAGCCAGCAGCTGGCTGTGGCTGTCATGTCTCTGACTCTGGGCACCTTC 60 ATTCTGACTCCTGGTCAGCAGCTCGCGGTGGCCATCTTAGCCCTCACCCTGGGCACGTTT 60

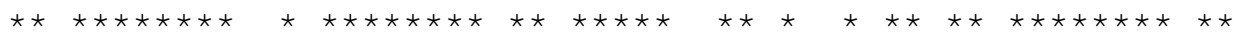

ACGGTGCTGGAGAACCTGGTGGTGCTCTGCGTCATCCTACAGTCCCGCACCCTCCGCTGC 120 ACAGTGCTGGAGAACCTCATGGTGCTGTGCGTGATCCTGCACTCTCATACGCTTCGGTCC 120

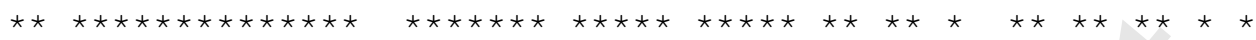

CGGCCGTCCTACCACTTCATTGGCAGTCTGGCTGTGGCTGACCTGCTGGGCAGCGTCATC 180 CGGCCATCCTACCACTTCATAGCCAGCCTGGCGGTCGCCGATCTCATAGGGAGCATCATT 180

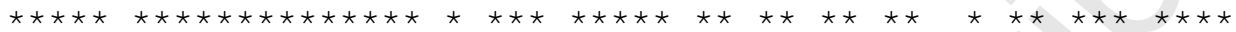

TTTGTCTACAGCTTTCTGGACTTCCATGTTTTCCACAGGAAAGACAGCCCTAATGTTTTT 240 TTTGTCTACAGCTTCCTGGACTTCCACGTCCTCCACCGGAAGGACAGTCAAAATGTTTTC 240

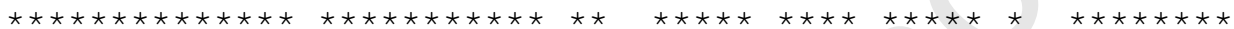

CTCTTCAAGCTGGGTGGAGTCACGGCGTCGTTCACAGCGTCTGTGGGGAGTCTTTTCCTC 300 CTCTTCAAGTTGGCCGGCGTCATCGCCTCCTTCACCGCGTCCGTGGGGAGTCTGTTCCTC 300

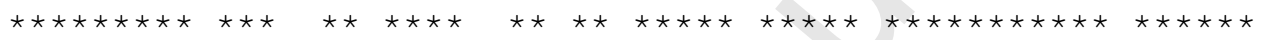

ACAGCTATCGACCGCTACATCTCCATACACCGGCCTCTTGCCTACAGGCGCATTGTGACA 360 ACGGCGATCGACCGGTACATCTCCATCCACAGGCCCATGGCGTACAAGCGCATCGTCACG 360

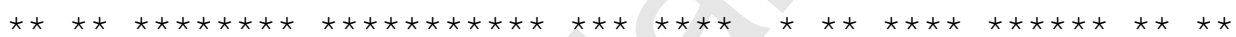

CGGACCAAGGCTGTCATAGCCTTTTGTTTGATGTGGACCATCTCCATTGTCATCGCAGTG 420 AAGACTAAGGCCGTCATCGCCTTCACCGTGATGTGGACGATCTCCATCGTGATTTCCCTG 420

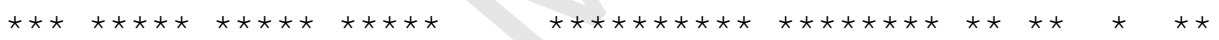

TTACCTCTGCTGGGCTGGAACTGTAAGCGTCTCAACTCTGTGTGCTCAAACATATTCCTT 480 CTGCCGCTGCTCGGCTGGAACTGCAAGCGCCTCAACTCCGTCTGCTCGGACATCTTCCCC 480

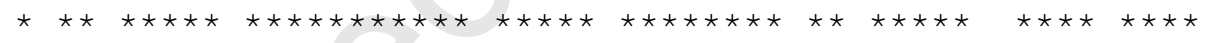

CTCATTGATAAGAACTACCTGATGTTCTGGATCGGTGTAACCAGCGTGCTGGTTCTTTTC 540 CTGATTGACGAGAATTATCTGATGTTCTGGATTGGAATGACGACCATCTTGGTCCTGTTC 540

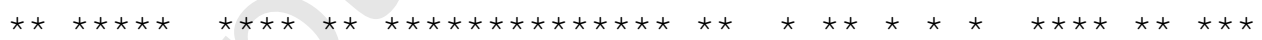

ATCATCTACGCCTACATATACATCCTGTGGAAGGCACACCACCATGCTGTGCGCATGCTG 600 ATCATCTACGCGTACATGTTCATCCTCTGGAAGTCCCACCACCACGCTGTCCGCATGATG 600

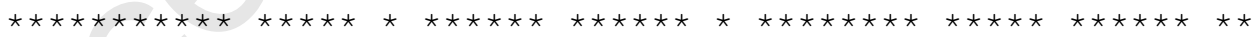

AGCCGAACCTCCCAGAAGAGCCTCGTCGTTTACTCAGCAGATGGGACTAAAGTGCAGACC 660 AGCCGCAGCTCCCAGAGAAGCGTGATTGTCTACACCGCAGAGGGGACCAGGGTTCAGACG 660

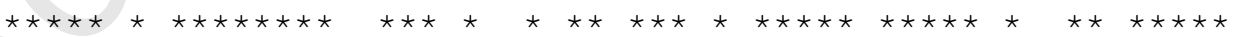

ACACGCCCTGAGCAGGCACGCATGGACATCCGATTGGCCAAGACCCTGGTGCTCATCTTG 720 ATAAGGGGCGAGCAGGCGCGGATGGACCTCCGCCTGGCCAAAACCCTAGTTCTGATCCTG 720

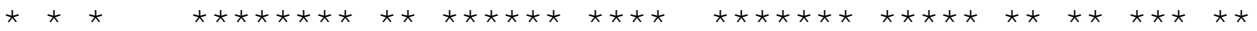

GTGGTGCTGGTTATCTGCTGGGGCCCGGTGCTCGCCATCATGGTCTACGACCTCTTCTGG 780 GTGGCCCTCATCATCTGCTGGGGCCCACTCTTGGCCATCATGGTCTACGACCTTTTCGGG 780

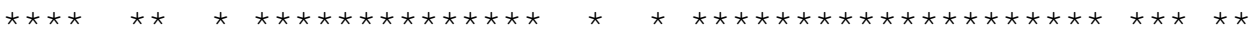

AGGATGGACGATGACATCA 799

AAGGTGAACGACTTCATCA 799

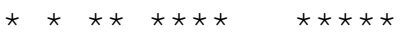




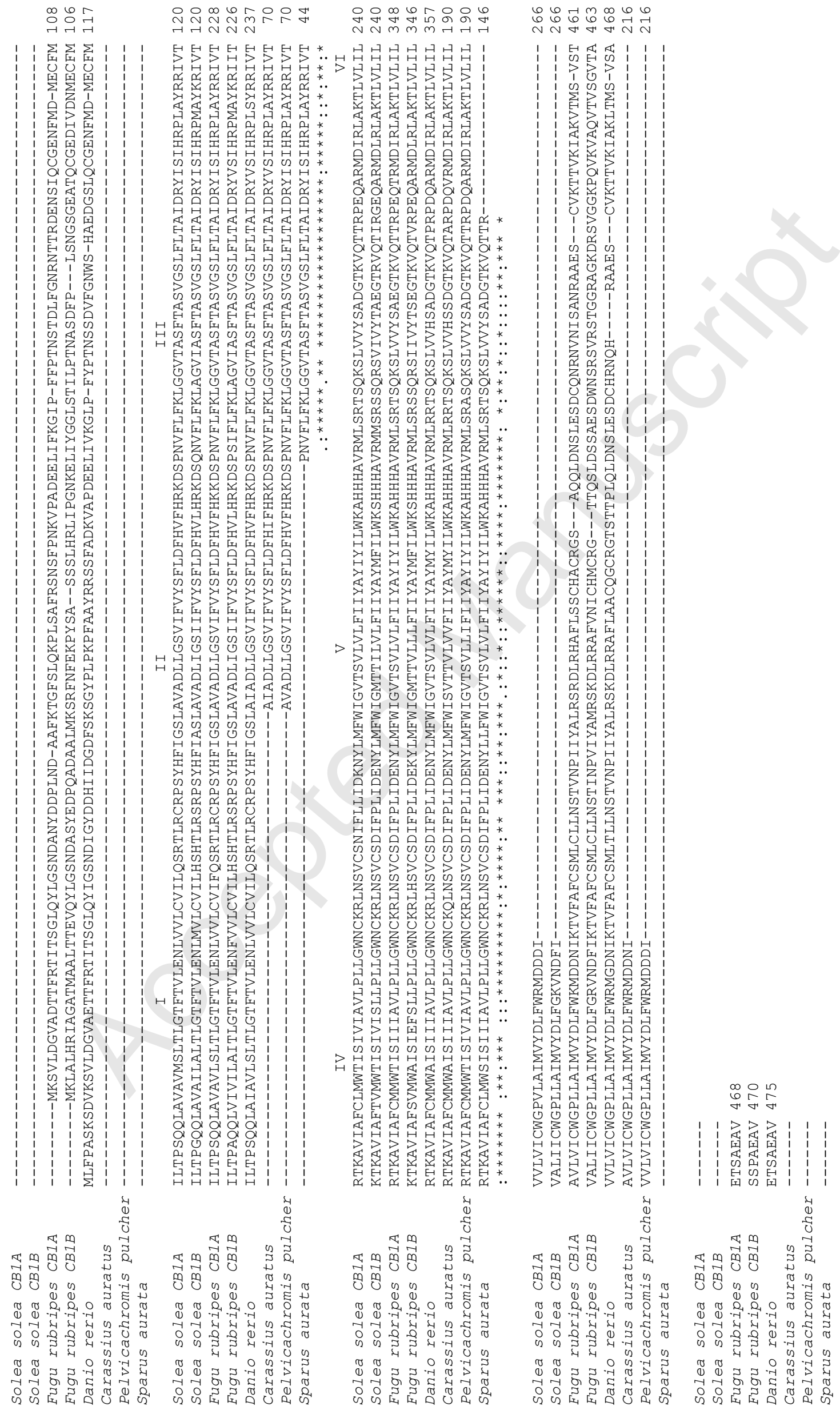


Fig 3
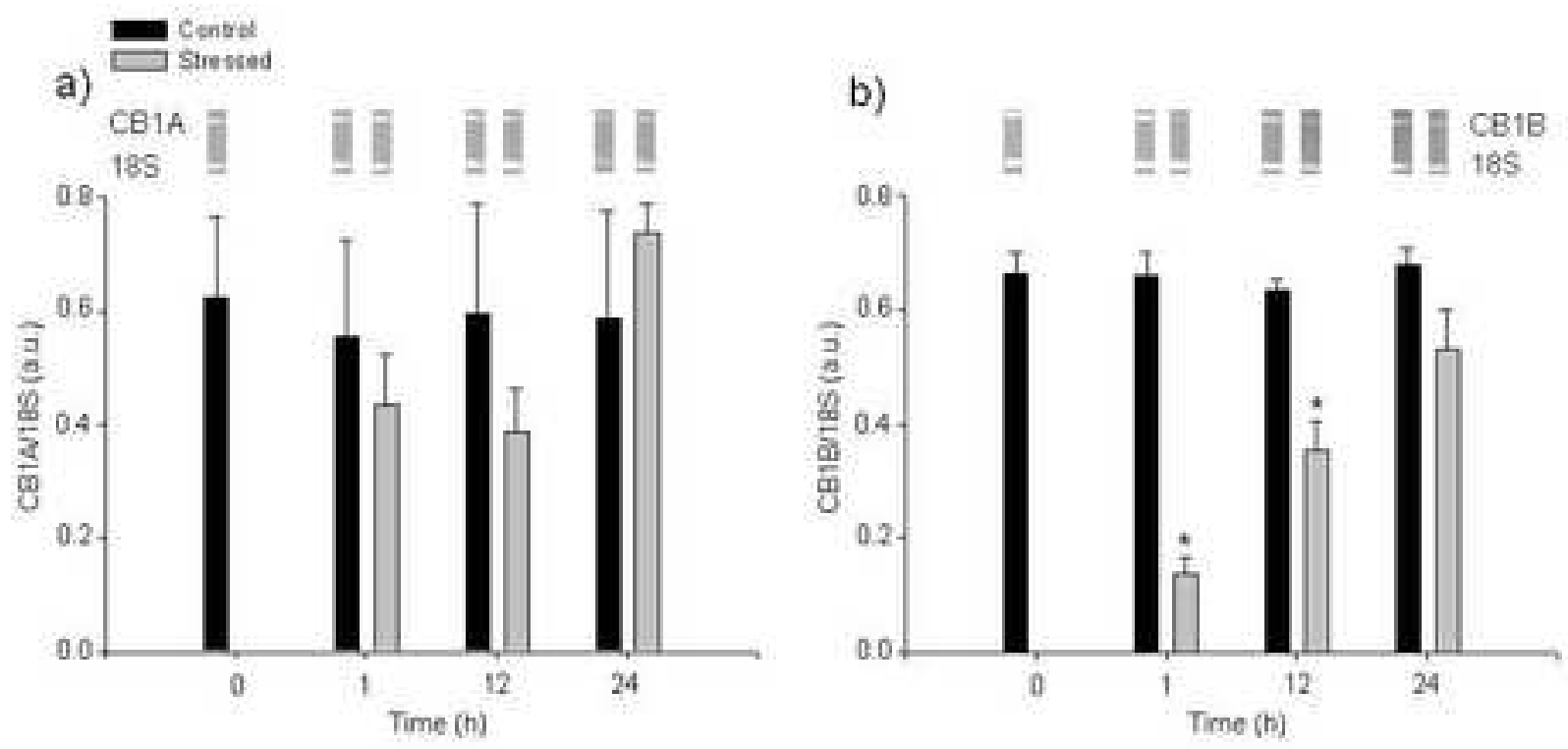
Fig 4

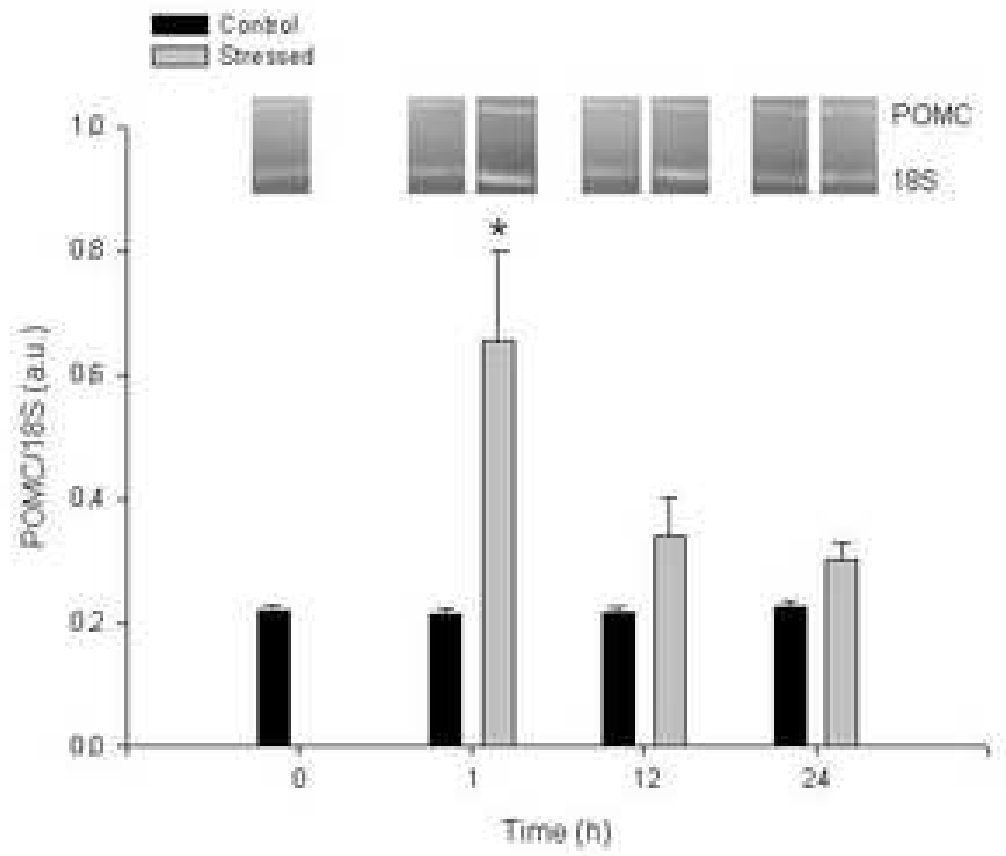

Page 20 of 21 
Fig 5

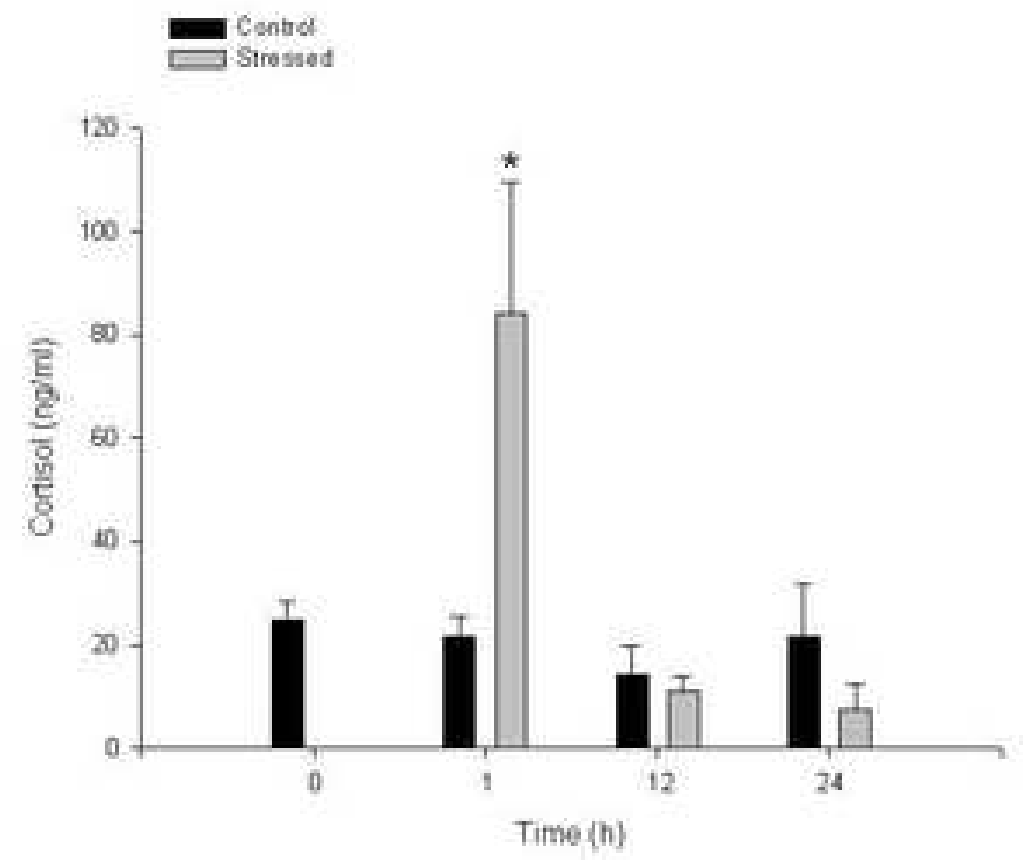

Page 21 of 21 